\title{
Implementasi Tasawuf Syekh Abdul Qadir al-Jailani dalam Majelis Manakib Al Barokah Ponorogo
}

\author{
Moh. Ashif Fuadi ${ }^{\boxplus}$ \& Rustam Ibrahim² \\ ${ }^{1}$ Program Studi Sejarah Peradaban Islam Fakultas Adab dan Bahasa IAIN \\ Surakarta \\ ${ }^{2}$ Program Studi Pendidikan Agama Islam Pascasarjana IAIN Surakarta \\ 凶moh.ashiffuadi@iain-surakarta.ac.id
}

Riwayat naskah:

Diterima: 2 November 2020

Disetujui: 3 Desember 2020

Diterbitkan: 8 Desember 2020

\begin{abstract}
One of the most popular sufi figures in the world is Shekh Abdul Qadir al-Jailani. The significant number of followers is due to his tremendous knowledge in various fields. In the reciting activities of Shekh Abdul Qadir al-Jailani's manakib explained his life history and grandeurs. In some of his works, he explains the teachings of sufism so that manakib practitioners can live up more to this. Also, he states to what extent the values of sufism are applied. The purpose of writing this article is to find out the sufism teachings of al-Jailani referring to his work and to know the implementation of his Sufism teachings in the Al Barokah Ponorogo manakib assembly with their routine agenda on the 11th night of the Hijri month. This study employs library sources combined with field observation on the assembly's activities. The results show that the sufism teachings of al-Jailani in the book al-Ghunyah Li Thalib Thariq alHaq are mujahadah, tawakkal, good morals, gratitude, patience, ridha, honesty, which in its implementation through the explanation and example of kiai have been practiced by the congregation of Al Barokah manakib and manifested in social behaviors.
\end{abstract}

Keywords: al-Jailani, jamaah, manakib assembly, tasawuf.

Abstrak: Salah satu tokoh sufi yang terpopuler di dunia adalah Syekh Abdul Qadir al-Jailani. Banyaknya penggemar tokoh sufi tersebut disebabkan oleh ketinggian ilmunya di berbagai bidang. Dalam kegiatan pembacaan kitab manakib Syekh Abdul Qadir al-Jailani, dijelaskan sejarah hidup berikut karomah-karomahnya. Dalam beberapa karyanya ia menjelaskan ajaranajaran tasawuf sehingga bisa semakin dihayati oleh pengamal manakib serta sejauh mana nilainilai ajaran tasawuf diterapkan oleh pengamalnya. Tujuan penulisan artikel ini untuk mengetahui ajaran-ajaran tasawuf al-Jailani merujuk pada karyanya dan mengetahui implementasi ajaran tasawufnya di majelis manakib Al Barokah Ponorogo yang diselenggarakan rutin tiap tanggal 11 bulan Hijriyah. Kajian ini menggunakan sumber pustaka dipadukan dengan pengamatan lapangan pada kegiatan majelis tersebut. Hasil penelitian menunjukkan bahwa ajaran tasawuf al-Jailani dalam kitab al-Ghunyah Li Thalib Thariq al-Haq adalah mujahadah, tawakkal, akhlak baik, syukur, sabar, ridha, jujur yang dalam implemetasinya melalui penjelasan dan keteladanan kiai sudah dipraktekkan oleh jamaah Al Barokah dan terwujud dalam perilaku sosial.

Kata kunci: al-Jailani, jamaah, majelis manakib, tasawuf.

P-ISSN 1907-1191 E-ISSN 2540-9204 @ 2020 pada penulis.

Diterbitkan oleh LP2M INSURI Ponorogo, artikel jurnal ini dapat diakses secara terbuka dengan lisensi CC-BY-SA. DOI: 10.37680 /adabiya.v15i02.576 


\section{Pendahuluan}

Dunia sufisme atau yang lebih dikenal dengan tasawuf sering mendapatkan tuduhan, sorotan dan kritikan yang tajam. Tidak sedikit orientalis Barat dan intelektual Muslim yang menuduh tasawuf sebagai faktor penghambat kemajuan umat Islam dan menjadi penyebab ketertinggalan Islam dalam percaturan dunia modern. Golongan yang anti dengannya biasanya datang dari kalangan yang kurang memahami ajaran tersebut secara menyeluruh. Mereka menganggap bahwa beberapa ajaran tasawuf seperti qanaah, zuhud, tawakkal, khauf dan lain-lain membuat seseorang menjadi malas, bodoh, miskin dan terbelakang. Terlebih tuduhan kelompok Islam puritan (wahabi) beranggapan bahwa tasawuf sebagai bid'ah yang menyesatkan karena tidak ada dasar dan tuntunannya dari Rasulullah dan para sahabatnya. ${ }^{1}$

Secara akar teologis sebenarnya tasawuf mempunyai dasar kuat al-Qur'an dan hadist sebagaimana keilmuan yang lain. Pada perkembangannya di tengah-tengah masyarakat yang ahli dalam bidang tasawuf dan melahirkan konsep masing-masing, terdapat perbedaan dan persamaan yang muncul di antara mereka. Hal ini membuktikan bahwa tasawuf menjadi disiplin ilmu yang otoritatif dengan adanya nuansa integral antara dimensi lahir dalam hal ini adalah ilmu fikih dengan tasawuf sebagai dimensi batin. Tokoh sufi populer, Syekh Abdul Qadir al-Jailani, mampu mengharmonikan antara dua dimensi tersebut sehingga antara ajaran tasawuf dan fiqih bisa berjalan bersama. Ia juga merupakan sufi terbesar di zamannya yang mempunyai kontribusi signifikan terhadap perkembangan sufisme yang terlembaga dalam wadah tarekat. Kedudukannya yang tinggi membuat ia menjadi pemimpin para wali (sulthân al-auliyâ') dan wali kutub (qutubu al-auliyâ). Ia juga menjadi sosok sentral di kalangan pecinta sufi seperti pengamal kitab manakib yang bersanding bersama keindahan karomah-karomah yang sangat luar biasa sehingga mendapat predikat muhyiddin (penghidup agama) sebagaimana yang termaktub dalam Manakib Nurul Burhani karya Syekh Muslih Mranggen.

Dalam pembacaan biografi Syekh Abdul Qadir al-Jailani atau dikenal dengan kegiatan manakiban, terdapat inspirasi nilai-nilai sufisme yang bisa diimplementasikan dalam kehidupan sehari-hari, khususnya bagi para pengamal manakib, dengan lebih menekankan pada aspek batiniah dengan tazkiyatun nafs (perjernihan hati) sehingga berimplikasi pada pembenahan ruang lingkup spiritual dan sosial seperti dengan raja' (mengharap rahmat Allah), khauf (mempunyai rasa takut kepada Allah), melatih ikhlas dan membersihkan segala penyakit hati riya (pamer), iri, sombong, dengki, dan lain sebagainya. ${ }^{2}$ Sebagaimana yang diungkapkan oleh Haryati dan Kosim bahwa degradasi moral kemanusiaan yang semakin meningkat memberi peluang terhadap konsep tasawuf akhlaki sebagai solusi di tengah krisis saat ini. Lebih lanjut, esensi spiritualitas menjadi potensi utama yang melekat pada diri manusia yang tidak mudah sirna meski dihadapkan dengan puncak rasionalitas dan disrupsi zaman milenial saat ini. ${ }^{3}$

Salah satu majelis manakib yang mengidolakan sosok al-Jailani adalah Majelis Manakib Al Barokah Ponorogo. Majelis tersebut dirintis oleh KH Iman Suyono pada tahun 1983 bersama beberapa sahabatnya dengan mengadakan kegiatan rutinan yang dikenal sewelasan dengan

\footnotetext{
${ }^{1}$ Said Aqil Siradj, Tasawuf Sebagai Kritik Sosial: Mengedepankan Islam Sebagai Inspirasi Bukan Aspirasi, I (Bandung: Mizan, 2006), 34.

2 Nur Yasin \& Sutiah, "Penerapan Nilai-Nilai Tasawuf Dalam Pembinaan Akhlak Santri Pada Pondok Pesantren Miftahul Huda Gading Malang", Jurnal Al-Musannif, Vol. 2 No. 1 (2020): 49-68.

3 Tri Astutik Haryati \& Mohammad Kosim, Tasawuf Dan Tantangan Modernitas, Jurnal Ulumuna, Vol. 14, No. 2 (2010): 413-428.
} 
agenda rutin tiap malam ke-sebelas kalender Hijriah. Majelis tersebut bukan hanya mengamalkan manakib tetapi juga amalan lainnya seperti Dzikrul Ghofilin karya Gus Miek Kediri, semaan alQur'an, sholawatan, dan lain sebagainya. Pada perkembangannya, kegiatan majelis tersebut bertranformasi secara multifungsi ke arah pendidikan dan kegiatan sosial keagamaan di bawah naungan Yayasan Pondok Pesantren Al Barokah Ponorogo. ${ }^{4}$

Dalam pengamatan penulis, salah satu bentuk injeksi spiritual tasawuf secara tersirat bisa diamati dalam kegiatan manakib yang secara berulang-ulang dengan dibacakannya biografi Syekh Abdul Qadir al-Jailani. Ajaran tasawuf juga bisa dilihat dalam beberapa karyanya dimana pengamal manakib bisa mengambil inti sari ajaran dan keteladanan yang tersurat di dalamnya dan diimplementasikan dalam kehidupan sehari-hari. Potret nilai-nilai keteladanan waliyullah tersebut sangat menginspirasi dalam banyak hal, terutama dalam proses mujahadah dan akhlakul karimah yang tercermin dalam hal-hal praksis baik secara vertikal (hablu minallah) dan secara horizontal (hablu minannas). Akses kebermanfaatan implementasi nilai ajaran tasawufnya tidak hanya sebatas pada jamaah saja namun pada akhirnya saling berintegrasi kepada akhlak para santri yang tinggal di pondok pesantren ini.

Berdasarkan alasan tersebut penulis ingin menggali lebih dalam tentang konsep ajaran tasawuf tokoh sufi terbesar tersebut melalui beberapa karyanya. Dengan menelusuri lebih jauh kegiatan Jamaah Al Barokah Ponorogo yang mempunyai ciri khas pengamal kitab manakib, penulis ingin mengkaji implementasi nilai-nilai tasawuf Syekh Abdul Qadir al-Jailani yang tidak terpisahkan dengan karakter jamaah manakib. Dengan menyelami ruh spiritual tasawuf berikut penerapan nilai-nilai yang terkandung di dalamnya, penulis berusaha untuk mampu lebih mempertajam kajian epistemologi tasawuf imam para wali tersebut berikut dengan nilai kemaslahatan yang diterapkan.

\section{Metode}

Artikel ini merupakan penelitian yang memadukan antara penelitian lapangan dengan literatur (library research). Dalam penelitian ini akan digunakan sumber data primer dan sekunder. Menurut Arikunto sumber data primer bisa diperoleh melalui pengamatan dan pencatatan lapangan, sedangkan sumber sekunder bisa melalui bacaan. ${ }^{5}$ Penelitian lapangan dilakukan dengan mengamati fenomena kegiatan Majelis Manakib Al Barokah yang dikenal dengan rutinan sewelasan berkaitan dengan pemahaman ajaran sufistik al-Jailani dan implementasi nilai-nilainya antara bulan Juni dan November 2020. Kiai di majelis tersebut, sebagai pendiri majelis juga mempunyai Pondok Pesantren Al Barokah. Sedangkan ajaran tasawuf Syekh Abdul Qadir alJailani bisa dikaji dengan cara dengan membaca karya-karyanya.

Dalam metode pengumpulan data penulis melakukan observasi di lapangan, melakukan wawancara yang terkait ditunjang dengan berbagai dokumentasi dan informasi yang sudah ada sebelumnya kemudian dianalisis melalui tahap reduksi, penyajian dan penarikan simpulan. ${ }^{6}$ Sumber data yang dipergunakan yaitu kepustakaan yang relevan secara manual menggunakan

${ }^{4}$ Arif Zein Rifa'i, Peran Kiai Dalam Menumbuhkan Sikap Kepedulian Sosial Jamaah Manakib Al Barokah Ponorogo, (IAIN Ponorogo, 2020), 40-41.

${ }^{5}$ Suharsimi Arikunto, Prosedur Penelitian: Suatu Pendekatan Praktik (Jakarta: Rineka Cipta, 2010), 35.

${ }^{6}$ Sugiyono, Memahami Penelitian Kualitatif (Bandung: Alfabeta, 2016), 14. 
buku ataupun sumber dari daring (online) dengan melihat penelitian terdahulu yang relevan seperti jurnal penelitian M. Arif Khoruddin, ${ }^{7}$ Siti Maryam Munjiat, ${ }^{8}$ tugas akhir Arif Zein Rifa'i, ${ }^{9}$ dan lain-lain kemudian data yang diperoleh, disaring dan diseleksi sesuai yang diperlukan. Tahapan berikutnya yakni penulisan, yang dilakukan secara runtut, logis, dan sistematis.

\section{Mengenal Tokoh Sufi al-Jailani}

Abdul Qadir al-Jailani dilahirkan di kawasan Jilan atau dalam versi yang lain Kailan suatu kota di Thabaristan perkampungan kecil di antara pegunungan Iran pada Ramadhan tahun $471 \mathrm{H}$. Sementara yang lain berpendapat ia lahir pada tahun $470 \mathrm{H}$ bertepatan dengan $1077 \mathrm{M}$ dan meninggal di usia 91 tahun di daerah Bab al-Ajaz Baghdad tanggal 11 Rabi'ul Akhir $561 \mathrm{H}$ bertepatan pada 1166 M. ${ }^{10}$ Adapun nasabnya dari jalur ayah adalah al-Jailani bin Abi Shalih Musa Janki Dausat bin Abdillah bin Yahya Zahid bin Muhammad bin Dawud bin Musa bin Abdillah bin Musa bin Abdullah Mahdhi bin Hasan II bin Sayyidina Hasan bin Ali bin Abi Thalib atau putra dari Fatimah Az-Zahra binti Muhammad Rasulullah. ${ }^{11}$

Sedangkan dari jalur ibu bernama Fatimah binti Abdillah bin Mahmud bin Abi al-Atha bin Kamaluddin bin Abi Abdillah Alauddin bin Ali Ridlo bin Musa Kazim bin Jakfar ash-Shadiq bin Muhammad Baqir bin Ali Zainal Abidin bin Husain bin Fatimah Az-Zahra putri Nabi Muhammad. Silsilah kedua orang tuanya bersambung kepada baginda Rasulullah dan banyak yang menyebutkan sebagai silsilah rantai emas. ${ }^{12}$

Sebagaimana kesepakatan itu dirangkum oleh cucu al-Jailani yaitu Muhammad Fadil, sekaligus penyunting tafsir al-Jailani, dalam perspektif sufistik al-Jailani merupakan sosok yang diagungkan dan menjadi ikon para wali Sultan al-Auliya, al-Qutb al-Rabbani, al-Ghauts, al-Baz $a l$-Ashab dan lain-lain. Dan semuanya itu merupakan gelar dari al-Jailani karena mempunyai keistimewaan yang luar biasa dibandingkan dengan ulama-ulama lain. ${ }^{13}$

Sejak kecil ia sudah ditinggal ayahnya dan diasuh oleh sang kakek dari pihak ibu, Abdullah as-Sumu'i. Abdul Qodir al-Jailani memiliki adik laki-laki bernama Abdullah, seorang anak yang shalih dan meninggal ketika masih remaja. Ia dilahirkan ketika ibunya sudah berusia 60 tahun. Kewalian sudah tampak di masa ketika ia masih bayi yaitu dengan tidak mau menyusui ibunya seperti sedang berpuasa mulai terbitnya fajar sampai tenggelamnya matahari, sehingga pernah pada suatu hari masyarakat dalam menentukan buka puasa mengikuti bayi al-Jailani. Ia terdidik dengan pendidikan akhlak dan ilmu serta berbagai keilmuan lainnya yang mengutamakan akhirat.

\footnotetext{
${ }^{7}$ M Arif Khoiruddin, "Peran Tasawuf Dalam Kehidupan Masyarakat Modern", Jurnal Tribakti: Jurnal Pemikiran Keislaman, Vol 27, No. 1 (2016): 113-30.

${ }^{8}$ Siti Maryam Munjiat, "Peran Tasawuf Dalam Pendidikan Karakter", Jurnal Al-Tarbawi Al-Haditsah: Jurnal Pendidikan Islam, Vol 3 No. 2 (2018).

9 Rifa'i, Peran Kiai. 77.

${ }^{10}$ Abdul Qadir Al-Jailani, Al-Fath Ar-Rabbany Wa Al-Faidh Ar-Rahmany (Beirut: Dar al-Kutub al-Ilmiah, 2010), 5 .

11 Al-Jailani, Al-Fath Ar-Rabbany, 5.

${ }^{12}$ Abdul al-Razaq Al-Kaylani, Abdul Qadir Jailani: Al-Imam Al-Zahid Al-Qudwah (Damaskus: Dar al-Qalam, 1994), 88.

13 Muhammad Fadil Al-Jailani, Nahr Al-Qadiriyah, 1st ed. (Istanbul: Markaz Al-Jailani li al-Buhuts alIlmiyah, 2009), 73.
} 
Dikisahkan bahwa saking asyiknya ia menimba ilmu dan melakukan proses tirakat sampaisampai ia hampir lupa untuk menikah. ${ }^{14}$

Pada usia delapan belas tahun ia merantau ke Baghdad tahun $488 \mathrm{H}$ abad ke-5 $\mathrm{H}$ dimana kota itu merupakan pusat peradaban dan pengetahuan Islam yang paling maju. Abdul Qadir alJailani terobsesi menuntut ilmu ke Baghdad karena merupakan tempat Imam Ahmad bin Hambal, seorang sosok yang sangat dikagumi oleh penduduk Jilan. Pada saat bersamaan tahun tersebut ulama masyhur pengarang kitab Ihya Ulumiddin Abu Hamid al-Ghazali juga baru meninggalkan pengajaran di madrasah al-Nizamiyah kemudian mengasingkan diri di Syam Baghdad. Dalam beberapa sumber disebutkan bahwa al-Jailani hidup sezaman dengan al-Ghazali, namun tidak ditemukan bahwa ia berguru kepada al-Ghazali. Selain itu ia juga hidup dalam periode yang sama dengan beberapa ulama besar lainnya seperti Ibnu Qayyim al-Jauzi, Az-Zuzani Ibnu Qudamah, Umar Khayam, al-Qusyairi, dan Syekh Abu Umar ibnu ash- Shalah. ${ }^{15}$

Karena sifatnya yang sangat jujur dan tekad mencari ilmu yang kuat, al-Jailani menjalani tirakat-tirakatnya dalam menuntut ilmu dengan istikamah menjalankan puasa di siang hari. Ia bertemu dengan Hammad bin Muslim al-Dabbas yang nantinya akan jadi guru spiritual dalam bidang tasawufnya. Ia merupakan wali besar di zamannya berprofesi sebagai seorang penjual sirup dimana Abdul Qadir muda berkeinginan untuk menuntut ilmu kepadanya. Syekh Hammad merupakan sosok pendidik yang tidak berorientasi pada dunia - dalam istilah tasawuf disebut zuhud, sehingga hal itu menurun kepada al-Jailani yang menutup diri dari dunia selama sebelas tahun. Dan di akhir masa ini berakhirlah masa latihan ruhaniyah batiniyah-nya sehingga alJailani menerima pancaran cahaya ilahiyyah yang dicarinya. ${ }^{16}$

Dalam proses pendidikannya, ia belajar berbagai disiplin ilmu di bidang fikih kepada Abu al-Khoththob Mahfudz bin Ahmad al-Khalwadzani dan Abu al-Wafa Ali yang bermadzhab Hambali. Dalam bidang ilmu sastra bahasa mengambil sanad kepada Abu Zakariya Yahya atTibrizy. Dalam bidang ilmu Hadis mengambil ilmu kepada Abu Ghain al-Baqilani, Ibnu Khunais, Abu Hanaim al-Rasi, Abu Bakar al-Tamara dan Abu Muhammad al-Sirraj. Dalam bidang tafsir dan ilmu al-Qur'an berguru kepada al-Wafa Ali bin Aqil dan Abu al Khottob Mahfudz alKhalwadzani (sebagaimana mengambil ilmu fikih), Abu al-Barakat Hibbatullah al-Mubarak, Abd al-Rahman bin Ahmad bin Yusuf, Abu Ghanaim, dan lain-lain. ${ }^{17}$ Sedangkan al-Jailani belajar ilmu penyucian hati kepada Hammad bin Muslim al-Dabbas sebagaimana juga diafirmasi oleh Ibnu al-Immad. Terkait ketekunan yang luar biasa ini, Ibnu Taimiyyah menyatakan bahwa alJailani dan gurunya Hammad bin Muslim al-Dabbas adalah ahli ilmu yang istikamah. ${ }^{18}$

Dalam beberapa keterangan disebutkan bahwa fikih madzhab Hambali dan Syafi'i merupakan ilmu yang paling ditekuni oleh al-Jailani. Setelah menguasai ilmu fikih ia kemudian melengkapinya dengan tasawuf kepada Abu Said Mukhrami dan juga Nabi Khidr. Selain itu, ia juga mempunyai murid, di antaranya yang populer adalah Ibnu Qudamah penyusun al-Mughni yang bercorak fikih dan Abdul Ghani penyusun Umdatul Ahkam fi Kalami Khairi al-Anam . ${ }^{19}$

${ }^{14}$ Abdul Qadir Al-Jailani, Al-Ghunyah Li Thalib Thariq Al-Haqq, II (Beirut: Dar al-Ihya at-Turats al-'Arab, 1996), 9.

${ }^{15}$ Al-Kaylani, Abdul Qadir Jailani: Al-Imam Al-Zahid Al-Qudwah, 99.

${ }^{16}$ Abdul Qadir Al-Jailani, Futuhul Ghoib Penyingkap Keghaiban (Yogyakarta: Titah Surga, 2015), 5.

${ }^{17}$ Al-Kaylani, Abdul Qadir Jailani: Al-Imam Al-Zahid Al-Qudwah, 102.

${ }^{18}$ Anis Masduki, Metode Tafsir Sufistik Abdul Qadir Al-Jailani (Yogyakarta: STIQ An-Nur, 2010), 67.

${ }^{19}$ Abdul Qadir Al-Jailani, Sirr Al-Asrar Wa Madhhar Al-Anwar (Kairo: Mathba'ah al-Mishriyah, 1969), 23. 
Sepeninggal al-Jailani, para putra dan muridnya mendirikan suatu tarekat untuk mengembangkan dan melembagakan tradisi sufisme dengan nama tarekat Qadiriyah yang sampai sekarang masih ada. ${ }^{20}$ Tarekat Qadiriyah berpegang teguh pada prinsip syariat dan paling kredibel dari segi sanadnya sehingga paling banyak diikuti oleh umat Islam sedunia. Terkait aliran Qadiriyah, Ibnu Taimiyyah yang notabene tergolong ulama tekstualis mengatakan bahwa Tarekat al-Jailani merupakan merupakan tarekat yang sesuai dengan prinsip dasar syariat Islam. ${ }^{21}$ Sebagai penguat, Martin van Bruinessen menyebutkan bahwa tarekat Qadiriyah muncul setelah beberapa generasi kemudian di Indonesia dengan tidak secara massif pada awalnya. Meskipun demikian, memang sangat mungkin al-Jailani mempunyai ajaran yang khusus yang tidak disebarkan kecuali kepada murid-murid terdekatnya saja. ${ }^{22}$

Abdul Qadir al-Jailani terlahir pada pada masa Bani Saljuk. Kondisi saat itu tengah dilanda pergolakan baik internal dan eksternal dalam hal ideologi yang berdampak pada kesengsaraan rakyat. Namun ia tetap konsisten di dalam menempa keilmuannya dan pembinaan masyarakat. ${ }^{23}$ Ahmad Kamaluddin Hilmi menyebutkan bahwa masa pemerintahan Saljuk yaitu pada masa Izzul Muluk bin Nizhamul Muluk masa kepemimpinan perdana menteri Barkyaruk, ditandai dengan kezaliman dan kemerosotan moral serta hedonisme kerajaan. Disebutkan oleh Ali bin Abi Ali alQumi bahwa pada masa itu adalah masa kesuraman. ${ }^{24}$ Dengan kondisi tersebut, banyak kalangan dari orang terkenal yang lari mengasingkan diri dan bertasawuf dalam hidupnya karena merasa prihatin. Sehingga dari kenyataan ini tasawuf hidup dengan subur. Tokoh-tokoh sufi yang bermunculan pada masa itu adalah al-Ghazali, al-Jailani, al-Anwari, as-Sinai, dan Dahiruddin alFaryabi. ${ }^{25}$

Ringkasnya, al-Jailani hidup di masa pertengahan Daulah Abbasiyah yang saat itu dalam masa pergolakan krisis politik baik dari dalam maupun luar. Selain itu ditandai dengan kezaliman dan kemerosotan moral dari para penguasa dan masyarakat. Keadaan seperti itu tidak sebanding dengan keadaan keramaian intelektual dan megahnya peradaban di Baghdad pada masa itu. Dikarenakan kota itu sebagai pusat pendidikan dan menjadi sentral peradaban untuk menuntut ilmu. ${ }^{26}$ Dengan melihat situasi itu, al-Jailani terdorong untuk mengambil jalur anti mainstream dengan melawan arus hedonisme memilih jalur kebenaran istikamah mengajar, berdakwah dan memegang teguh prinsip prinsip batiniah dengan mengikuti kata hati nurani sebagai pancaran nur ilahiyyah berkebalikan dengan situasi dekadensi moral. ${ }^{27}$

Sebagian ulama salaf seperti Imam Sya'rani menilai bahwa al-Jailani mengkompromikan madzhab Hambali dan Syafi'i dalam ilmu fikih. ${ }^{28}$ Madzhab Hambali yang dianggap skriptual ternyata bisa sinergis dalam sufisme menerima cahaya kebenaran. Ada yang berpendapat bahwa keteguhan al-Jailani dalam madzhab Hambali ini untuk mempertahankannya dari kepunahan. Hal ini dibuktikan oleh salah satu muridnya, Ibnu Qudamah yang kemudian mempunyai peranan

${ }^{20}$ Al-Kaylani, Abdul Qadir Jailani: Al-Imam Al-Zahid Al-Qudwah, 127. Lihat juga Abdul Wahhab (w.593 H), Abdul Razaq (w.603), Abdus Salam (w.611 H)

${ }^{21}$ Al-Jailani, Sirr Al-Asrar Wa Madhhar Al-Anwar, 28.

${ }^{22}$ Martin Van Bruinessen, Kitab Kuning, Pesantren Dan Tarekat (Yogyakarta: Gading Publising, 2015), 260.

${ }^{23}$ Ahmad Kamaluddin Hilmi, As-Salajiqah Fi at-Tarikh Wa Al-Hadharah (Kuwait: Dar al-Buhuts al-Ilmiah, 1975), 197.

${ }^{24}$ Hilmi, 200.

${ }^{25}$ Abul Hasan An-Nadwi, Rijal Al-Fikri Wa Ad-Dakwah Fi Al-Islam (Kuwait: Dar al-Qalam, 1969), 237.

${ }^{26}$ Al-Kaylani, Abdul Qadir Jailani: Al-Imam Al-Zahid Al-Qudwah, 105.

${ }^{27}$ Al-Kaylani, 105.

${ }^{28}$ Al-Sha'rani, Tabaqat Al-Kubra (Kairo: Dar al-Fikr al-Arabi, 1994), 109. 
besar dalam melestarikan Madzhab Hambali. ${ }^{29}$ Hal ini membuktikan bahwa ajaran tasawuf alJailani bersifat universal dan toleran dalam interaksi antara Tuhan dengan manusia, sehingga menjadi pedoman yang lebih adaptif.

Untuk menyelamatkan kemerosotan akhlak yang terjadi di masa itu, al-Jailani berusaha melakukan upaya tabayun konsepsi akidah melalui tasawuf. Tasawuf dalam pandangan al-Jailani adalah integrasi keilmuan yang berlandaskan al-Qur'an dan Hadis serta konsistensi pengamalan ajaran Islam dengan menjernihkan jiwa dan pikiran melalui pembersihan hati, yaitu dengan cara mengaktualisasikan diri menyembah kepada Allah dengan sungguh-sungguh dan memiliki akhlak yang terpuji ketika berinteraksi dengan manusia. ${ }^{30}$ Ciri khas sufisme al-Jailani adalah mengatur dua dimensi rasional, pertama; secara vertikal hubungan manusia dengan Tuhan dalam bentuk ibadah, kedua; hubungan horizontal sesama manusia sebagai makhluk sosial dalam berinteraksi. Dengan demikian paradigma sufistik al-Jailani adalah integrasi ilmu dan amal.

\section{Pandangan Tasawuf Abdul Qadir al-Jailani}

Pada dasarnya tasawuf merupakan implementasi dari syariat yang menekankan pada perbaikan moral. ${ }^{31}$ Dalam salah satu karangannya, Syekh Abdul Qadir al-Jaelani beberapa pengertian tasawuf sesuai dengan huruf-hurufnya. ${ }^{32}$ Dengan huruf $t a$ ' yang pertama adalah taubat yang berarti penyucian hati dari beberapa sifat yang madzmûumah (sifat yang tercela) dengan rasa penyesalan yang sungguh-sungguh dan mendalam disertai permohonan ampun serta meninggalkan segala perbuatan yang menimbulkan dosa. ${ }^{33}$ Sedangkan menurut al-Ghazali, taubat diklasifikasikan ke dalam tiga tingkatan, yaitu (1) Sikap pengendalian dari berbuat dosa dan beralih kepada kebaikan karena takut kepada siksa Allah; (2) Selalu berusaha lebih baik. Dalam tasawuf, keadaan ini diistilahkan kepada inabah; dan (3) rasa penyesalan yang dilakukan sematamata karena rasa mahabbah kepada Allah, hal ini diistilahkan dengan taubat. ${ }^{34}$

Selanjutnya adalah huruf shad yang berasal dari kata shafa' bermakna kesucian, kebeningan atau kejernihan. Ada dua hal yang bisa dijelaskan dari huruf ini yakni yang pertama Shafa' al-Qalb bermaksud bahwa hati ini dibersihkan dari hal-hal yang bisa mengotorinya, seperti menggunjing, berprasangka buruk dan banyak membaca aib orang. Cara membersihkan adalah senantiasa membasahi lisan dengan mengucapkan kalimat dzikir sampai merasa senantiasa dilihat/diperhatikan oleh Allah. Kemudian Shafa as-Sirr yang mempunyai makna beriman dan bertakwa kepada Allah selalu berusaha melantunkan nama nama Allah dengan dengan cara halus dan samar. ${ }^{35}$ Maka di sinilah kita bisa melihat perpaduan antara dzikir jahr (keras) dan sirri (samar) yang dipadukan oleh Syeikh Ahmad Khatib Sambas dalam menformulasi tarekat Qadiriyah wa Naqsyabandiyah yang juga memadukan dua metode dzikir tersebut.

${ }^{29}$ Al-Kaylani, Abdul Qadir Jailani: Al-Imam Al-Zahid Al-Qudwah, 126.

${ }^{30}$ Al-Jailani, Nahr Al-Qadiriyah, 185.

${ }^{3}$ M. Amin Syukur, Tasawuf Kontekstual Solusi Problem Manusia Modern (Yogyakarta: Pustaka, 2003). Dalam Jurnal Nuraini \& Nelly Marhayati, Peran Tasawuf Terhadap Masyarakat Modern, Jurnal Studi Keislaman Vol. 19, No. 2 (2019): 297-320.

32 Al-Jailani, Sirr Al-Asrar Wa Madhhar Al-Anwar, 76.

${ }^{33}$ Al-Jailani, Sirr Al-Asrar Wa Madhhar Al-Anwar, 77.

${ }^{34}$ Totok Jumantoro \& Samsul Munir Amin, Kamus Ilmu Tasawuf, II (Jakarta: Amzah, 2012).

${ }^{35}$ Al-Jailani, Sirr Al-Asrar Wa Madhhar Al-Anwar, 78. 
Dari kata shafa' (kejernihan) mengandung yang menunjukan keterbebasan diri dari kotoran, bahkan kata sufi sendiri salah satunya juga berasal dari kata shafa'. Sang sufi adalah hamba Allah yang jiwa, hati, ruh dan rahasianya telah disucikan dengan dzikrullah, mujahadah, dan akhirnya menerima rahmat Allah sehingga hatinya telah menjadi tempat tinggal Allah. Berikutnya adalah huruf waw yang yang berasal dari kata wilayah berarti kebeningan dan kesucian jiwa. Hal ini bisa disesuaikan kebersihan lahir batin seorang hamba.Puncak dari hamba yang mendapatkan nya yaitu rasa patuhnya terhadap Allah dengan akhlak yang terpuji, baik kepada Allah maupun sesame manusia, sehingga terjadi kesesuaian antara intuisi dari tuhan terhadap penerapan akhlak sehari hari. ${ }^{36}$ Untuk menjelaskannya, terdapat hadits $q u d s i$ yang cukup populer dimana ketika semakin tinggi tingkat kecintaan hamba kepada tuhan-Nya, maka semakin tinggi pula kedekatan dan pertautan antara dia dengan Allah dalam dalam dimensi lahir dan batin dalam pendengaran, penglihatan dan semua gerak tubuhnya. ${ }^{37}$

Wilayah merupakan kewalian yang dimiliki para wali (auliya) Allah. Hal ini sebagai karunia Allah yang menunjukan ketinggian kesempurnaan manusia. Dasar kewalian adalah gnosis (makrifat) bukan kesucian atau kesalehan. Derajat pengetahuan mengenai Allah yang turun kepada wali juga sebagai karunia Allah. Wali yang memiliki wilayah bertugas menguak makna tersembunyi ajaran para Rasul. Mereka adalah juru bicara para rasul. Di dalam wilayah terdapat urutan hierarki yang berpuncak pada wali al-Quthb sebagaimana kedudukan Syekh Abdul Qadir al-Jailani.

Huruf yang terakhir adalah $f a$ ' menurut Syekh Abdul Qadir al-Jailani dalam karangannya berasal dari kata fana' yang berarti sirna/rusak. Dengan sifat ini berarti akan menghapus segala sifat kefanaan manusia sekaligus menyatakan keabadian sifat tuhan yang memberikan keridhoanNya kepada hamba yang mendapatkan rahmat kasih sayang. ${ }^{38}$ Ibrahim Madkur, berpendapat fana' yang dimaksudkan adalah hilangnya kesadaran terhapusnya seorang hamba dalam kebesaran Tuhan sesuai dengan amal baik yang diinvestasikannya dalam perilaku sehari hari. ${ }^{39}$ Dalam kamus tasawuf dijelaskan bahwa pengertian fana' adalah sirnanya kesadaran manusia terhadap segala hal yang bersifat inderawi sehingga yang betul betul ada secara hakiki dan abadi di dalam kesadarannya adalah wujud mutlak. ${ }^{40}$

Adapun konsepsi tasawuf amali Syekh Abdul Qadir al-Jilani dalam kitab al-Ghunyah Li Thalib Thariq al-Haq ${ }^{41}$ dijelaskan sebagai berikut: (1) Mujahadah, diriwayatkan dari Abu Said ak-Khudri, ketika Nabi Muhammad ditanya tentang jihad yang paling utama, beliau bersabda: "yaitu mengucapkan kebenaran di hadapan pemimpin yang dzalim" (2) Tawakkal, "Abu Turab an-Nakhsyabi berkata, Tawakkal adalah menyibukkan diri dengan ibadah, menggantungkan hati kepada Allah, dan ridha terhadap sekalian takdir-Nya. Jika Allah memberinya, ia bersyukur. Jika tidak, ia bersabar." (3) Akhlak yang baik, "Abdullah bin Amru ra. Berkata, "Nabi Muhammad bukan seorang yang keji dan tidak bersikap keji." Beliau bersabda, "Sesungguhnya yang terbaik di antara kamu adalah yang paling baik akhlaknya." (HR. al-Bukhari)." (4) Syukur, Allah berfirman dalam QS. Ibrahim ayat 7. "Sesungguhnya jika kalian bersyukur, pasti kami akan

\footnotetext{
${ }^{36}$ Al-Jailani, Sirr Al-Asrar Wa Madhhar Al-Anwar, 78.

${ }^{37}$ Abdul Qadir Al-Jailani, Futuhul Ghoib (Kairo: Maktabah wa Mathba'ah al-Mishriyah, 1973), 15.

${ }^{38}$ Al-Jailani, Sirr Al-Asrar Wa Madhhar Al-Anwar, 79.

${ }^{39}$ Ibrahim Madkur, Fi Falsafah Islamiyah Manhaj Wa Tathbiquhu (Kairo: Dar al-Ma'arif, 1976), 25.

${ }^{40}$ Jumantoro \& Amin, Kamus Ilmu Tasawuf, 51.

${ }^{41}$ Al-Jailani, Al-Ghunyah Li Thalib Thariq Al-Haqq, 306-35.
} 
menambah [nikmat] kepada kalian. (5). Sabar, "Dzun Nun al-Mishri berkata: sabar adalah senantiasa menjauhi larangan, tabah menghadapi kepahitan (kesulitan), dan tetap menampakkan kecukupan ketika ditimpa kemiskinan." (6) Ridha, "Dan diucapkan juga bahwa ridha adalah senangnya hati menerima pahitnya musibah yang menimpa dirinya." (7) Shiddiq, "Jujur berarti menegaskan kebenaran meskipun dapat menyebabkan nyawa terancam. Atau kejujuran itu adalah kesesuaian antara isi hati dengan perkataan, ada juga yang mengatakan bahwa jujur adalah tidak menyalahi janji Allah dengan menjalankan amal ibadah kepada-Nya." 42

Meskipun Syekh Abdul Qadir al-Jailani tidak merumuskan konsep tasawuf secara rigid dan sistematis, namun ia lebih menekankan proses sufisme tersebut dengan langkah-langkah yang substantif yang esensinya tidak bergeser dari intisari ajaran tasawuf mulai dari proses pertaubatan, penjernihan hati dan integrasi ilmu dan amal. ${ }^{43}$ Syekh Abdul Qadir al-Jailani berhasil mengharmonikan syariat dengan tasawuf sama halnya dengan al-Ghazali. Ia menekankan pada peningkatan amal di dunia yang akhirat oriented atau berorientasi pada akhirat, proses penjernihan hati melalui Tazkiyat an-Nafs menjadi bagian yang mutlak untuk dilalui oleh pelaku suluk melalui proses mujahadah yang buahnya adalah mencapai kedudukan makrifat mengenal Allah. ${ }^{44}$

\section{Implementasi Tasawuf Al-Jailani Majelis Manakib Al Barokah Ponorogo}

Majelis Manakib Syekh Abdul Qadir al-Jailani didirikan oleh KH Iman Suyono pada tahun 1983 dan berlokasi di Kelurahan Mangusuman Kecamatan Siman Kabupaten Ponorogo. Hal itu tidak lepas dari dukungan masyarakat Mangunsuman dan salah satu gurunya yang bernama $\mathrm{KH}$ Maghfur Hasbullah, pengasuh Pondok Pesantren Darul Hikam Kauman Pasar Pon Ponorogo, untuk mendirikan sebuah Jamaah Manakib sebagai wujud mencintai kekasih Allah. Adapun ijazah manakib tersebut diperoleh dari KH Husnuddin Dolopo Madiun, KH Nur Salim Pakis Malang, KH Maksum Kedung Gudel Ngawi, dan KH Hannan Maksum Kwagean Pare Kediri. Selain itu, ia juga tabbarukan kepada KH Arsyad Yogyakarta, Gus Mad Watucongol Muntilan (KH Abdul Haq), KH Muhsin Jambu Madiun, KH Ma'ruf Jalen Ponorogo, KH Hasyim Sholeh Mayak, KH Khirzuddin Hasbullah Joresan, KH Mukhlas Hasbullah Coper, KH Syamsul Huda Kertosari, KH Fatkhurrozi Pulung dan KH Imam Suhadi Bagbogo Nganjuk. Kegiatan itu dilakukan untuk meminta saran dan masukan sekaligus doa restu untuk mengamalkan manakib.

Melalui isyarat KH Maghfur Hasbullah ketika sowan ke salah seorang kiai di Gresik, ia melihat kondisi keluarga kiai tersebut cukup harmonis dengan melihat anak-anak di sana berbakti kepada orang tuanya. Setelah KH Maghfur menanyakan kepada kiai tersebut tentang amaliyah keseharianya, ia menjawab bahwa amalannya adalah melazimi manakib. Setiap waktu longgar malam Jumat, kiai dari Gresik tersebut istikamah menyembelih ayam jantan dengan niat tabbarukan Syekh Abdul Qadir al-Jailani dari anak-anaknya satu per satu bergiliran setiap malam Jumat. Kemudian KH Maghfur berusaha mengamalkan amaliyah yang serupa, namun karena kesibukan sebagai seorang mubaligh, maka kegiatan tersebut sering digantikan oleh santrisantrinya, salah satunya adalah Imam Suyono.

${ }^{42}$ Khafidhotul Ilmia \& Saifulah, "Konsepsi Tasawuf Amali Syekh Abdul Qadir Al-Jailani Dalam Kitab A1Ghunyah Li Thalib Thariq Al-Haq", Jurnal Al-Ghazwah Vol.1, No. 2 (2017): 184-85.

${ }^{43}$ Al-Jailani, Futuhul Ghoib, 13.

${ }^{44}$ Al-Jailani, Al-Fath Ar-Rabbany, 52. 
Di saat kesibukan KH Maghfur semakin bertambah maka Imam Suyono ingin mengamalkan manakib secara berjamaah, oleh KH Maghfur Hasbullah dianjurkan untuk meminta ijazah kepada KH Khusnuddin Dolopo Madiun. Setelah meminta restu maka amalan tersebut mulai diamalkan. Bahkan beberapa kali Kiai Husnuddin berkenan hadir dari Dolopo Madiun ke Ponorogo untuk mengisi dan mengijazahkan manakib. ${ }^{45}$

Melalui pengamatan penulis dengan mengikuti berbagai kegiatan Majelis Al Barokah, baik yang ada di dalam Pondok Pesantren ataupun kegiatan-kegiatan rutin di luarnya, sebagian besar konsep tasawuf Syekh Abdul Qadir al-Jailani sudah diajarkan oleh pengasuhnya yaitu KH. Imam Suyono. Ia membimbing jamaah ke arah yang lebih baik untuk bekerja dan beribadah untuk tujuan akhirat sebagaimana konsep tasawuf al-Jailani yang mengemukakan konsep al-Dunya mazro'atu al-Akhiroh yang berarti dunia adalah lahan menanam pahala yang panennya nanti berupa kebahagiaan di akhirat. Hal ini tidak lepas dari keteladanan pengasuh Majelis Al Barokah yang banyak memberi contoh dari perangai akhlak kehidupan daripada perkataan seperti berdakwah dengan membaca kitab manakib al-Jailani dan mengajarkan ajarannya ke pelosokpelosok kampung dengan istikamah tanpa pamrih, memberikan teladan untuk menjaga hubungan sosial dengan menjenguk orang sakit, melayat terhadap saudara muslim yang meninggal, dan memberikan bantuan finansial kepada tetangga atau jamaah yang dalam keadaan ekonomi sulit. Menurut Soejarno Soekanto, peran merupakan aspek yang dinamis dari kedudukan (status). Artinya, seorang yang telah menjalankan hak-hak dan kewajiban-kewajiban sesuai dengan kedudukannya, maka orang tersebut telah melaksanakan suatu peran. ${ }^{46}$

Dalam mentrasnsmisikan ajaran tasawuf al-Jailani, pengasuh seringkali mengajak kepada para jamaah untuk melaksanakan ajaran Islam secara konsekuen, baik untuk diri mereka sendiri maupun keluarga, saudara-saudara dan sanak familinya. Salah satu penyebab keberhasilan dakwah Rasulullah adalah karena ia dapat dijadikan teladan bagi umatnya. Sebagaimana difirmankan dalam surat Al-Ahzab ayat 21 yang artinya "Sesungguhnya telah ada pada (diri) Rasulullah itu suri tauladan yang baik bagimu". ${ }^{47}$ Selain itu, dalam tataran teoritis pengasuh seringkali mengingatkan kepada para jamaah dan santri terus belajar ilmu syariat yang dipadukan dengan dimensi batiniah melalui mujahadah, mengembangkan sifat tawakkal, membiasakan diri dengan akhlakul karimah, memperbanyak bersyukur, melatih kesabaran, selalu ridha terhadap segala pemberian Allah, dan membiasakan diri untuk berbuat jujur. Hal ini senada dengan ajaran tasawuf al-Jailani dalam salah satu kitabnya al-Ghunyah Li Thalib Thariq al-Haq.

Dalam pengamatan penulis, penyampaian ajaran tasawuf biasanya dilakukan pada acara pembukaan sebelum dimulainya kegiatan rutin manakiban dengan membedah isi dari kitab Nurul Burhani yang berisi biografi dan laku spiritual pemimpin para wali berikut dengan ajaran praksisnya yang menyeimbangkan dipadukan dengan contoh-contoh nyata dalam kehidupan sosial berdasarkan pengalaman-pengalamannya. Dengan merujuk karya al-Jailani Sirr Al-Asrar Wa Madhhar Al-Anwar dalam konsepsi tasawufnya, pengasuh seringkali menyinggung tentang pentingnya bertaubat kepada Allah, menjernihkan jiwa, membeningkan hati dan mengakui kebesaran Allah dan kelemahan makhluk-Nya.

${ }^{45}$ Wawancara dengan KH Imam Suyono (Pengasuh Majelis Manakib Al Barokah) di Ponpes Al Barokah 23 September 2020

${ }^{46}$ Soerjono Soekanto, Teori Peranan (Jakarta: Bumi Aksara, 2002), 243.

${ }^{47}$ Departemen Agama, Al-Qur'an Dan Terjemahnya (Jakarta: Departemen Agama, 2000), 379. 
Selain itu, dikaji juga kitab-kitab bercorak tasawuf karya Imam Ghazali yaitu kitab Bidayatul Hidayah, Minhajul Abidin dan kitab tasawuf karangan ulama salaf yang lain seperti Nashoihud Diniyyah, Irsyadul 'Ibad, Adzkar Nawawi dan lain sebagainya di Pondok Pesantren untuk memperkuat pemahaman sufisme. Sebagai pengasuh, ia selalu menekankan kepada para jamaah untuk berperan memberikan manfaat di lingkungan dengan mengikuti kegiatan sosial baik yang bersifat kerja sosial lingkungan maupun keagamaan. Hal tersebut penting untuk menjaga hubungan sosial dengan sesama manusia sesuai dengan konsep hablu minannas.

Proses implementasi ajaran tasawuf di Majelis Al Barokah tidak hanya diajarkan aspek transfer of knowledge (pengetahuan) dimana seorang hamba hendaknya selalu mendekatkan diri kepada Allah, mencintai Nabi Muhammad dan meneladani Syekh Abdul Qadir al-Jailani, namun juga dalam aspek transfer of value diberikan pendidikan nilai nilai kemanusiaan dicontohkannya dengan keteladanan yang baik dan selalu dihimbau untuk berbuat baik terhadap sesama dimanapun berada. Hal itu terwujud dalam role model pengasuh yang istikamah berdakwah hingga pelosok kampung tanpa imbalan, menghadiri undangan pengajian tanpa membedakan status sosial, dan menekankan kepada para jamaah untuk beribadah kepada Allah baik yang wajib maupun sunah. Ia juga mendidik para santri di Pondok Pesantren Al Barokah dengan sabar dan istikamah membangunkan para santri secara langsung berkeliling di kamar-kamar sebelum waktu Shubuh dan memberikan contoh nyata pentingnya menjaga kebersihan di pesantren.

Temuan penulis tersebut juga diperkuat dengan wawancara terhadap salah satu putra menantunya yaitu Gus Khozinul Minan yang menyatakan: "Beliau memiliki wawasan yang luas tentang kemasyarakatan, sosok yang istikamah, dermawan, penyabar, hormat kepada yang lebih tua, hormat pada guru-gurunya, beliau juga seorang pejuang yang militan serta telaten tanpa pamrih mengurusi jamaah tanpa melihat status sosial, dibuktikan dengan jamaah yang makin banyak. Jamaah tersebut bediri dari tahun 1983 hingga sekarang masih eksis dan terus berkembang. Sikap beliau dalam ranah sosial yakni tidak membeda-bedakan status sosial, status ekonomi dari jamaahnya, ketika sudah dalam kegiatan jamaah semua dianggap sama. Karena sikap-sikap itulah menjadi seorang dihormati dan disegani oleh jamaahnya maupun santrinya tidak ada yang merasa lebih unggul dari yang lain ". ${ }^{48}$

Peran KH Imam Suyono dalam menumbuhkan sikap kepedulian sosial jamaah sangatlah banyak. Beliau adalah seorang kyai yang memegang kendali penuh dalam jamaah Manakib Al Barokah dan mampu menjadi suri tauladan bagi jamaahnya. Contoh sikap beliau dalam melaksanakan perannya yakni beliau selalu mencontohkan terlebih dahulu sebelum memerintah jamaahnya. Ketika beliau menyuruh untuk membantu kepada orang yang tidak mampu, maka beliau sudah lebih dulu memberi contoh bagaimana caranya membantu yang baik dan benar. Beliau juga memberikan solusi terbaik apabila ada dari jamaah mempunyai permasalahan keluarga, ekonomi, dan sosial.

Hal ini diperkuat dengan wawancara terhadap pengasuh : "Saya di sini berusaha berperan sebagai seseorang mampu memberikan contoh yang baik kepada jamaah dan santri dengan selalu mengajak dan mengingatkan dalam hal kebaikan. mengingatkan kapan pun dan di mana pun harus berbuat baik terhadap sesama manusia. Khususnya dalam hal bermasyarakat serta selalu mendoakan jamaah agar selalu diberikan kesehatan lahir batin. Hal yang penting saat kita

48 Wawancara dengan Gus Khozinul Minan (Putra Menantu Ponpes Al Barokah) di Ponpes Al Barokah Ponorogo 23 Oktober 2020. 
berdakwah yakni kita harus melakukanya terlebih dahulu sebelum menasehati/menyeru kebaikan kepada sesama. Dakwah yang demikian akan lebih diterima masyarakat daripada hanya perkataan saja namun tidak diikuti dengan tindakan langsung. Misalkan ketika kita menyeru untuk bersedekah maka kita harus terlebih dahulu untuk bersedekah ". ${ }^{49}$

Dengan keteladanan yang diberikannya, penulis melihat bahwa jamaah Al Barokah memiliki ikatan kekeluargaan kuat dan egaliter dalam wujud gotong royong berupa tenaga, pikiran, materi dan bentuk partispasi jamaah yang lain. Dalam hal ini sangat membutuhkan penerapan nilai tasawuf sikap ikhlas, sabar dan qanaah. Contoh konkretnya adalah setiap kegiatan rutin yang akan baik yang bersifat mingguan maupun bulanan akan diadakan, masing-masing jamaah akan memberi partisipasi sesuai dengan kemampuannya dengan sukarela. Dalam hal gotong-royong terlihat saat pengecoran lantai gedung madrasah Al Barokah pada bulan Juli 2020, ratusan jamaah berbodong-bondong dengan sukarela datang untuk mendermakan tenaganya menyelesaikan proses pembangunan. Hal ini merupakan imbas dari implementasi nilai tasawuf al-Jailani tersalurkan melalui ajaran kiai terhadap santrinya yang bersikap luwes dalam dakwahnya sehingga diterima dengan baik oleh banyak kalangan.

Dari penelitian Arif Zein Rifa'i terkait dengan karakter Jamaah Majelis al Barokah dapat diketahui bahwa peran kiai dalam membina Majelis Al Barokah sangat relevan dengan ajaran tasawuf al-Jailani yakni akhlak yang baik dan sabar. Dalam skripsi tersebut dalam bab kesimpulan dijelaskan bahwa dengan menjalankan peran sentralnya secara maksimal untuk menjadi suri tauladan bagi jamaahnya, mendidik dengan memberikan contoh nyata, menghidupi jamaah, memberikan sikap perhatian dan pengertian yang sama dan tidak membedakan bedakan antar jamaah serta ikut aktif terjun langsung dalam kegiatan. Sebagaimana disebutkan bahwa heterogenitas pandangan agama dan tradisi di Ponorogo bisa menjadi dasar untuk melakukan relasi akomodasi dan kerjasama. ${ }^{50}$ Penelitian itu merupakan hasil observasi penelitiannya selama mengikuti kegiatan manakiban dan menjadi santri di Pondok Pesantren Al Barokah Ponorogo. Lebih lanjut dijelaskan bahwa peran sebagai role model tersebut dilaksanakan dengan tindakan nyata dan terencana untuk keberhasilan dalam mencapai tujuan mendekatkan diri kepada Allah serta menciptakan jamaah yang peduli antar sesama. ${ }^{51}$

Menurut Miftah Nur Masyriqi dalam penelitiannya menyebutkan bahwa sikap kepedulian jamaah manakib Al Barokah terhadap sesama yakni mengembangkan gotong royong antara sesama, materi dan pemikiran secara terencana sebagai untuk menyukseskan kegiatan. Peran sentral KH Imam Suyono sosok yang mampu menjadi suri tauladan, pendidikan dengan memberikan contoh nyata karena adanya kemajemukan daripada jamaah dengan adanya latar belakang pendidikan, ekonomi, dan lingkungan sosial sehingga harus disesuaikan dengan ajaran Syekh Abdul Qadir Jailani yang diantaraya adalah memberi teladan dan melatih kesabaran. ${ }^{52}$

49 Wawancara dengan KH Imam Suyono (Pengasuh Majelis Manakib Al Barokah) di Ponpes Al Barokah Ponorogo 23 September 2020

${ }^{50}$ Arik Dwijayanto \& Dawam Multazamy Rohmatulloh, "Ponorogo, the Little Java: Potret Kebudayaan Dan Keberagamaan Masyarakat Muslim Ponorogo Abad XX", Al-Adabiya: Jurnal Kebudayaan Dan Keagamaan Vol.13, No. 01 (2018): 27-28. https://doi.org/10.37680/adabiya.v13i01.2

${ }^{51}$ Rifa'i, Peran Kiai, 77.

52 Miftah Nur Masyriqi, Nilai-Nilai Kepedulian Sosial Pada Kegiatan Jamaah Manakib Al-Barokah di Mangunsuman Ponorogo (IAIN Ponorogo, 2019), 75-76. 


\section{Kesimpulan}

Ajaran tasawuf Syekh Abdul Qadir al-Jailani dalam kitabnya Sirr Al-Asrar Wa Madhhar AlAnwar dijelaskan tentang empat hal yaitu: (1) taubat (2) shafa' (3) wilayah (4) fana'. Sedangkan dalam karyanya al-Ghunyah Li Thalib Thariq al-Haq terdapat tujuh hal ajaran tasawuf al-Jailani yaitu: (1) taubat (2) tawakkal (3) akhlakul karimah (4) syukur (5) sabar (6) ridho (7) shiddiq. Konsep ajaran tasawuf al-Jailani adalah tasawuf akhlaki amali yang menekankan pada segi-segi praktis yang berkaitan dengan tazkiyatun nafsi (pembersihan jiwa) melalui proses mujahadah. Ajaran tasawuf al-Jailani juga menekankan pada moral yang terpuji meninggalkan yang tercela, semakin tinggi moral seseorang maka itu akan menambah kebersihan jiwanya. al-Jailani juga mengatakan bahwa orang bertasawuf harus menyeimbangkan antara hubungan dengan tuhan dan sesama manusia. al-Jailani juga memadukan antara syariat dan sufisme secara praktis-aplikatif. Begitu juga implementasi ajaran tasawufnya, yang beberapa di antaranya sudah diterapkan jamaah Majelis Al Barokah Ponorogo. Bukan hanya terwujud dalam kegiatan ritual ibadah saja, namun juga terintegrasi dengan nilai-nilai sosial kemanusiaan. Nilai ajaran tasawuf al-Jailani terinternalisasi ke dalam pola kehidupan sehari hari melalui pengajaran dan keteladanan kiai kemudian tersinergikan antara ruang spiritual dengan sosial.

\section{Referensi}

Al-Jailani, Abdul Qadir. Al-Fath Ar-Rabbany Wa Al-Faidh Ar-Rahmany. Beirut: Dar al-Kutub alIlmiah, 2010.

—. Al-Ghunyah Li Thalib Thariq Al-Haqq. II. Beirut: Dar al-Ihya at-Turats al-`Arab, 1996.

_. Futuhul Ghoib. Kairo: Maktabah wa Mathba'ah al-Mishriyah, 1973.

—. Futuhul Ghoib Penyingkap Keghaiban. Yogyakarta: Titah Surga, 2015.

Sirr Al-Asrar Wa Madhhar Al-Anwar. Kairo: Mathba'ah al-Mishriyah, 1969.

Al-Jailani, Muhammad Fadil. Nahr Al-Qadiriyah. 1st ed. Istanbul: Markaz Al-Jailani li al-Buhuts al-Ilmiyah, 2009.

Al-Kaylani, Abdul al-Razaq. Abdul Qadir Jailani: Al-Imam Al-Zahid Al-Qudwah. Damaskus: Dar al-Qalam, 1994.

Al-Sha'rani. Tabaqat Al-Kubra. Kairo: Dar al-Fikr al-Arabi, 1994.

An-Nadwi, Abul Hasan. Rijal Al-Fikri Wa Ad-Dakwah Fi Al-Islam. Kuwait: Dar al-Qalam, 1969.

Arikunto, Suharsimi. Prosedur Penelitian: Suatu Pendekatan Praktik. Jakarta: Rineka Cipta, 2010 .

Bruinessen, Martin Van. Kitab Kuning, Pesantren Dan Tarekat. Yogyakarta: Gading Publising, 2015.

Departemen Agama. Al-Qur'an Dan Terjemahnya. Jakarta: Departemen Agama, 2000.

Dwijayanto, Arik, \& Dawam Multazamy Rohmatulloh. "Ponorogo, the Little Java: Potret Kebudayaan Dan Keberagamaan Masyarakat Muslim Ponorogo Abad XX". Al-Adabiya: Jurnal Kebudayaan Dan Keagamaan 13, No. 01 (2018). https://doi.org/10.37680/adabiya.v13i01.2

Haryati, Tri Astutik, \& Mohammad Kosim. "Tasawuf Dan Tantangan Modernitas". Ulumuna Vol 
14, No. 2 (2010). https://doi.org/10.20414/ujis.v14i2.224

Hilmi, Ahmad Kamaluddin. As-Salajiqah Fi at-Tarikh Wa Al-Hadharah. Kuwait: Dar al-Buhuts al-Ilmiah, 1975.

Ilmia, Khafidhotul, Saifulah. Konsepsi Tasawuf Amali Syekh Abdul Qodir Al-Jailani Dalam Kitab Al-Ghunyah Li Thalib Thariq Al-Haq. Al-Ghazwah Vol 1, No. 2 (2017).

Jumantoro, Totok, \& Samsul Munir Amin. Kamus Ilmu Tasawuf. II. Jakarta: Amzah, 2012.

Khoiruddin, M Arif. "Peran Tasawuf Dalam Kehidupan Masyarakat Modern". Tribakti: Jurnal Pemikiran Keislaman Vol. 27 No. 1 (2016). https://doi.org/10.33367/tribakti.v27i1.261

Madkur, Ibrahim. Fi Falsafah Islamiyah Manhaj Wa Tathbiquhu. Kairo: Dar al-Ma'arif, 1976.

Masduki, Anis. Metode Tafsir Sufistik Abdul Qadir Al-Jailani. Yogyakarta: STIQ An-Nur, 2010.

Masyriqi, Miftah Nur. Nilai-Nilai Kepedulian Sosial Pada Kegiatan Jamaah Manakib AlBarokah Di Mangunsuman Ponorogo. Skripsi IAIN Ponorogo, 2019.

Munjiat, Siti Maryam. "Peran Tasawuf Dalam Pendidikan Karakter". Al-Tarbawi Al-Haditsah: Jurnal Pendidikan Islam 3, No. 2 (2018). https://doi.org/10.24235/tarbawi.v3i2.3431

Nuraini, \& Nelly Marhayati. "Peran Tasawuf Terhadap Masyarakat Modern", Analisis : Jurnal Studi Keislaman 19, No. 2 (2019). https://doi.org/10.24042/ajsk.v19i2.3375

Rifa'i, Arif Zein. Peran Kyai Dalam Menumbuhkan Sikap Kepedulian Sosial Jamaah Manakib Al Barokah Ponorogo. IAIN Ponorogo, 2020.

Siradj, Said Aqil. Tasawuf Sebagai Kritik Sosial: Mengedepankan Islam Sebagai Inspirasi Bukan Aspirasi. I. Bandung: Mizan, 2006.

Soekanto, Soerjono. Teori Peranan. Jakarta: Bumi Aksara, 2002.

Sugiyono. Memahami Penelitian Kualitatif. Bandung: Alfabeta, 2016.

Syukur, M. Amin. Tasawuf Kontekstual Solusi Problem Manusia Modern. Yogyakarta: Pustaka, 2003.

Yasin, Nur, \& Sutiah. "Penerapan Nilai-Nilai Tasawuf Dalam Pembinaan Akhlak Santri Pada Pondok Pesantren Miftahul Huda Gading Malang". Al-Musannif vol. 2, no. 1 (2020). https://doi.org/10.5281/zenodo.3782293

Wawancara dengan Gus Khozinul Minan (Putra Menantu Ponpes Al Barokah) di Ponpes Al Barokah, Ponorogo, 23 Oktober 2020.

Wawancara dengan KH Imam Suyono (Pengasuh Majelis Manakib Al Barokah) di Ponpes Al Barokah, Ponorogo, 23 September 2020. 